\title{
Assessment of Physicochemical and Bacteriological Quality of Different Surface Water Samples of Tangail District, Bangladesh
}

\author{
Nasreen Jahan ${ }^{*}$, Safaiatul Islam¹, Fatematuz Zuhura Evamoni², Md. Jakir Hossain ${ }^{1}$, \\ Sabiha Akter³, Md. Ronzu Ahmmed1', Md. Ashraful Islam4', Shahin Mahmud'
}

${ }^{1}$ Department of Biotechnology and Genetic Engineering, Mawlana Bhashani Science and Technology University, Santosh, Tangail ${ }^{2}$ Department of Biotechnology and Genetic Engineering, Noakhali Science and Technology University, Sonapur, Noakhali, Bangladesh ${ }^{3}$ Department of Environmental Science and Resource Management, Mawlana Bhashani Science and Technology University, Santosh, Tangail

${ }^{4}$ Department of Statistics, Mawlana Bhashani Science and Technology University, Santosh, Tangail

Email: *naza.bge@gmail.com

How to cite this paper: Jahan, N., Islam, S., Evamoni, F.Z., Hossain, Md.J., Akter, S., Ahmmed, Md.R., Islam, Md.A. and Mahmud, S. (2017) Assessment of Physicochemical and Bacteriological Quality of Different Surface Water Samples of Tangail District, Bangladesh. Advances in Microbiology, 7, 769-789.

https://doi.org/10.4236/aim.2017.711062

Received: October 20, 2017

Accepted: November 27, 2017

Published: November 30, 2017

Copyright (c) 2017 by authors and Scientific Research Publishing Inc. This work is licensed under the Creative Commons Attribution International License (CC BY 4.0).

http://creativecommons.org/licenses/by/4.0/

\begin{abstract}
Surface water, a vital element of ecosystem must be hygienic, but unfortunately the pollution of this water is now an alarming problem. The present work deals with the assessment of physicochemical and bacteriological profile of several untreated surface water sources to ensure its suitability for using domestic purposes and drinking along with the impact of bacterial contaminated water on public health and antibiotic resistance pattern of these bacteria. The samples were collected from twenty sampling point (13 ponds, 4 lakes, 2 rivers and one canal) of Tangail District from January 2017 to June 2017. To understand the seasonal variation, water samples were measured in two month; February (dry season) and June (wet season). Most of the water sampling points were polluted by dumping of waste, cattle wash and were not suitable for the drinking or other domestic purposes. Obtained results showed that water of the study area is slightly alkaline, no remarkable variation in the temperature of the water in both seasons and DO of all the sampling station were lower than standard limit during February. The mean concentration (M.C.) of total Coliform were $4 \times 10^{22} \mathrm{cfu} / 100 \mathrm{ml}$ and $4.5 \times 10^{18} \mathrm{cfu} / 100 \mathrm{ml}$ at February and June respectively and all the sampling point were contaminated with fecal coliform. Other pathogenic bacteria, E. coli (M.C: $1.1 \times 10^{11} \mathrm{cfu} / 100 \mathrm{ml}$ at February and M.C: $2.2 \times 10^{7} \mathrm{cfu} / 100 \mathrm{ml}$ at June), Salmonella spp. (M.C: 1.1 $\times 10^{5} \mathrm{cfu} / 100 \mathrm{ml}$ at February and M.C: $3.4 \times 10^{5} \mathrm{cfu} / 100 \mathrm{ml}$ at June), Shigella spp. (M.C: $8 \times 10^{4} \mathrm{cfu} / 100 \mathrm{ml}$ at February and M.C: $3.4 \times 10^{7} \mathrm{cfu} / 100 \mathrm{ml}$ at June), Vibrio spp. (M.C: $8.6 \times 10^{5} \mathrm{cfu} / 100 \mathrm{ml}$ at February and M.C: $1.1 \times 10^{8}$
\end{abstract}


$\mathrm{cfu} / 100 \mathrm{ml}$ at June) were isolated from several of the investigated water sources. The total counts of these pathogenic bacteria exceeded the acceptable limit during both season and also showed resistance against a broad range of commercially available antibiotics. People who were using these water frequently suffering from various water borne diseases. These untreated water sources pose a major threat to the public health and therefore need for exigent intervention by government.

\section{Keywords}

pH, Dissolved Oxygen, Coliform, E. coli, Shigella spp., Salmonella spp., Vibrio spp., Antibiotic, Tangail

\section{Introduction}

Water is not only essential for the survival of any form of life, but also vital for the recreational aspects of life [1]. Although water envelope $80 \%$ of the earth surface, but only $3 \%$ are available for drinking, agriculture, domestic and industrial consumption [2]. This surface water from rivers, lakes, canals and ponds are vital resources of water that are necessary to the subsistence of all living organisms [3].

Low lying flat country, Bangladesh is fulfilled high number of upland water bodies including rivers, lakes, haors, baors, beels, ponds, cultivated fields with water inundated and estuarine systems with extensive mangrove swamps [4]. Most of the poverty stricken village people depend on these surface water for their daily purposes activities as they have no any potable water sources in Bangladesh [5]. But nowadays this valuable water resources are ominous, as directly exposure to people's domestic purposes, pollution from untreated industrial effluents, municipal wastewater, runoff from chemical industry and agricultural fields and oil and lube spillage from different operation, fecal contamination and aquatic pathogenic microorganisms [6]. Physical, chemical and biological properties of water known as water quality which have a direct influence on the types and distribution of aquatic biota [7]. Nowadays, the demotion of water quality due to the multifarious pollution is an alarming problem. Both conventional pollutants such as heavy metals, nitrate, phosphate, pesticides and micro pollutants worsen the water quality of the surface water bodies of the country [8].

Pathogenic microorganisms contaminate the water, is now a major global problem. The main causes of bacteria in the aquatic environment are the disposal of human waste and municipal waste water through sewage and drainage ditches systems. Human pathogenic bacteria, particularly members of the coliform can inhabit on fishes and aquatic environment [9]. Feces of warm-blooded animals can harbor fecal coliforms and they are the most commonly used indicators of fecal pollution in water and food. Increased levels of fecal coliforms provide a 
warning of failure of the water distribution system and possible contamination with other pathogens such as E. coli, shigella spp., salmonella Spp., Cholera etc. [10]. Water become unsafe for human consumption or usage when it contains pathogenic or diseases causing microorganisms. The consumption of unhygienic drinking water and uses of unsafe water for daily purposes lead to the prevalence of diseases like diarrhea, typhoid, cholera and bacillary dysentery among the population [11].

Besides, contaminated surface water with pathogenic bacteria, the presence of antibiotic resistant bacteria in these water bodies has become an emerging problem throughout the world [12]. This antibiotic resistance exacerbates the prevalence of waterborne diseases among the people of surrounding of these wetlands [13]. Therefore, the maintenance of good water quality is essential for healthy survival of aquatic organisms and people's good health those who are exposed to this water. However, there are only a few published data on the microbiological quality of wetland water and antibiotic resistance pattern of these microorganisms in few areas around the country. Our study was commenced to evaluate physicochemical and bacteriological profile of the several water bodies of Tangail districts as well as antibiotic resistance pattern of the bacteria associated with these water bodies.

\section{Materials and Methods}

\subsection{Study Area, Time and Sample Collection}

Our study was conducted at twenty selected water bodies including 13 ponds, 4 lakes, 1 canal and 2 rivers which are situated in Tangail sadar upazila, Bangladesh (Figure 1).

The study was carried out from January to July 2017. Approximately, $300 \mathrm{ml}$ of water samples were collected in $500 \mathrm{ml}$ of plastic bottles and before sample collection, all the plastic bottles were properly cleaned by distilled water. Bottles were immersed below the water surface, filled, brought out of the water and properly closed. Then they were properly labeled (sample no, source, date, time etc.) and samples were carried to the laboratory within the six hours of collection.

\subsection{Primary Data Collection}

Some primary data related to water contamination (such as-cattle wash, dumping of waste, opening of drains and latrines in water sources, color, odor, appearance of water bodies etc.) were collected with a semi-structured based questionnaire [14].

\subsection{Physiochemical Parameters Analysis}

$\mathrm{pH}$ was determined by the digital $\mathrm{pH}$ meter (Model: $\mathrm{pH}$ Scan WP 1, 2; Malaysia). The Dissolved Oxygen (DO) was determined by digital DO meter (Model: D.46974; Taiwan). Temperature was measured by the digital thermometer 


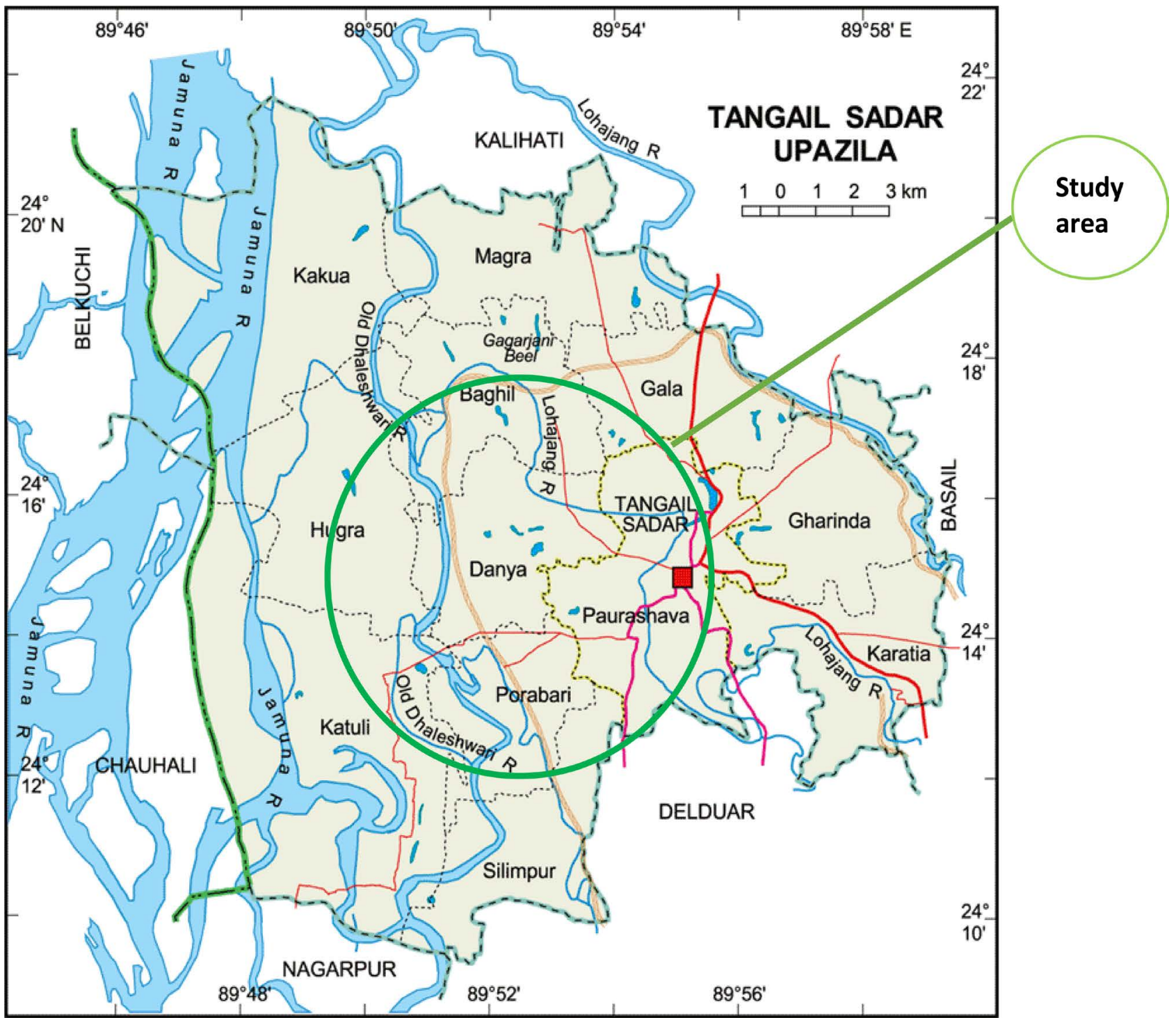

Figure 1. Map of the study area.

(GF-MT502, China).

\subsection{Microbial analysis}

\subsubsection{Total Coliform Count}

Most probable number (MPN) test was used to detect the presence of coliforms in sample water [15]. In presumptive MPN procedure, 15 lactose broth tubes were inoculated with the water samples. Five tubes received $10 \mathrm{ml}$ of water, 5 tubes received $1 \mathrm{ml}$ of water and 5 tubes received $0.1 \mathrm{ml}$ of water. The number of tubes showing gas production and color change was compared to a standard table developed by American Public Health Association. The number of coliform was the MPN of coliforms per $100 \mathrm{ml}$ of the water sample [16].

\subsubsection{Detection of Fecal Coliforms}

The positive presumptive cultures were transferred to lactose broth, which is 
specific for fecal coliform bacteria. Any presumptive tube which showed gas production after $24( \pm 2)$ hours incubation at $44.5^{\circ} \mathrm{C}\left( \pm 0.2^{\circ} \mathrm{C}\right)$, confirmed the presence of fecal coliform bacteria in that tube and was recorded as positive [17].

\subsubsection{Isolation of Pathogenic Bacteria}

To isolate specific pathogenic bacteria, the samples were enriched separately with alkaline peptone water (APW) for plating in thiosulfate citrate bile salts sucrose agar (TCBS) media, with GN (Gram-Negative) Broth for plating in Salmonella Shigella Agar (SS) agar, with Enterobacteria Enrichment Broth-Mossel for plating in MacConkey media. $1 \mathrm{ml}$ of water from each sample was added with $3 \mathrm{ml}$ of respective enrichment media. All the samples were then incubated at $37^{\circ} \mathrm{C}$ for 24 hours. After overnight enrichment, the samples were plated in MacConkey, TCBS and SS agar plate separately. All the plates were incubated at $37^{\circ} \mathrm{C}$ for 24 hours. After overnight incubation, the plates were observed for selective pathogens. For the confirmation of Escherichia coli, red/pink colonies form MacConkey agar plates were plated in eosin methylene blue agar (EMB) plates and for the confirmation of Vibrio cholerae and Vibrio parahaemolyticus, standard biochemical tests were performed from the yellow and green colonies in TCBS media respectively. Lactose fermenting (LF) and Non-LF bacteria were determined by differential media (MacConkey medium) to differentiate lactose fermenters (pink/yellow) colonies \& non lactose fermenter colonies (colorless). Lastly, conformation of Shigella spp., Salmonella spp. and their serotype was determined with the antisera (polyvalent) developed by Denka Seiken, Japan [18] [19].

\subsubsection{Antibiotic Sensitivity Test}

Antibiotic susceptibility test was performed by disk diffusion method using the commercially available antibiotic disk on Mullar-Hinton agar to assess the susceptibility and resistance pattern of the isolates [20]. For this purpose, 12 different antibiotic discs were obtained from commercial sources (Himedia, India and Oxoid Ltd. England).

\subsection{Evaluation of Environmental Human Health Impact}

A field investigation and random questionnaire based survey of 400 respondents (20 person from each sampling site) of the study area was conducted to determine the health status of people who used these water for bathing, Oju and other daily purposes.

\subsection{Statistical Analysis}

MS Excel 2010 and SPSS 20 software were used for calculating average and presentation of graphs. The relation among these parameters was determined by the Karl Pearson's co-relation coefficient and coefficient of co-relation (r). The one-way analysis of variance (ANOVA) was used to determine whether there are any statistically significant differences among parameters. 


\section{Result and Discussion}

\subsection{Physiochemical Parameters Analysis}

\subsubsection{Cattle Washing in the Sample Water Sources}

Cattle washing on public wetlands degrades water quality and sanctions concern microbial contaminants include fecal coliform and E. coli which are threatening to human and ecological health [21]. In our study, it was found that most of the water sample sources are not usually used for washing of cattle. Among twenty sample sources, one pond, two lakes and both rivers under study area were used for cattle washing activity by the people around it (Table 1 ).

Table 1. Sources of the collected water samples with location.

\begin{tabular}{|c|c|c|c|c|c|c|c|c|c|}
\hline \multirow[b]{2}{*}{$\begin{array}{l}\text { Water } \\
\text { sample }\end{array}$} & \multirow[b]{2}{*}{ Source name and Location } & \multirow[b]{2}{*}{$\begin{array}{l}\text { Cattle } \\
\text { wash }\end{array}$} & \multirow[b]{2}{*}{$\begin{array}{l}\text { Dumping } \\
\text { of waste }\end{array}$} & \multirow[b]{2}{*}{$\begin{array}{l}\text { Water } \\
\text { type }\end{array}$} & \multirow[b]{2}{*}{$\begin{array}{c}\text { Color of } \\
\text { water }\end{array}$} & \multicolumn{4}{|c|}{ Used for } \\
\hline & & & & & & $\begin{array}{l}\text { Drinking after } \\
\text { normal filtration }\end{array}$ & Cooking & Bath & Oju \\
\hline Pond-01 & Pir Shahjaman Dhighi, MBSTU campus & No & No & Normal & $\begin{array}{l}\text { Deep } \\
\text { Green }\end{array}$ & No & No & Yes & Yes \\
\hline Pond-02 & Rani Dinomoni dhighi, MBSTU campus & No & No & Normal & $\begin{array}{l}\text { Light } \\
\text { Green }\end{array}$ & No & No & Yes & Yes \\
\hline Pond-03 & Academic building pond, MBSTU campus & No & No & Normal & $\begin{array}{l}\text { Light } \\
\text { Green }\end{array}$ & No & No & Yes & Yes \\
\hline Pond-04 & Govt. girls high school pond, MBSTU campus & No & No & Normal & $\begin{array}{l}\text { Light } \\
\text { Green }\end{array}$ & No & No & Yes & Yes \\
\hline Pond-05 & Trustee Board pond, MBSTU campus & No & No & Normal & $\begin{array}{l}\text { Light } \\
\text { Green }\end{array}$ & No & No & Yes & Yes \\
\hline Pond-06 & Rani pond, MBSTU campus & No & No & Normal & $\begin{array}{l}\text { Deep } \\
\text { Green }\end{array}$ & No & No & Yes & Yes \\
\hline Pond-07 & Bokkhobadhi pond, Santosh, Tangail & No & Yes & Polluted & Gray & No & No & Yes & No \\
\hline Pond-08 & Santosh bazaar pond, Santosh, Tangail & No & Yes & Polluted & Turbid & No & No & No & No \\
\hline Pond-09 & Poraton para pond, Santosh, Tangail & Yes & Yes & Polluted & Brown & No & No & Yes & No \\
\hline Pond-10 & Zhannobi school pond, Santosh, Tangail & No & No & Normal & $\begin{array}{l}\text { Light } \\
\text { Green }\end{array}$ & No & No & Yes & Yes \\
\hline Pond-11 & Thanapara pond, Thanapara, Tangail & No & Yes & Polluted & Turbid & No & No & Yes & No \\
\hline Pond-12 & Sadar hospital pond, Tangail & No & Yes & Polluted & Turbid & No & No & No & No \\
\hline Pond-13 & Polytechnics pond, Tangail polytechnic Ins. & No & No & Normal & Brown & No & No & Yes & Yes \\
\hline Lake-14 & District Lake (north), District area, Tangail & No & Yes & Normal & $\begin{array}{l}\text { Deep } \\
\text { Green }\end{array}$ & No & No & Yes & Yes \\
\hline Lake-15 & District Lake (south), District area, Tangail & No & Yes & Polluted & Gray & No & No & Yes & No \\
\hline Lake-16 & Lake infront of Tangail polytechnical Inst. & Yes & Yes & Polluted & Turbid & No & No & No & No \\
\hline Lake-17 & DC lake, New bus stand, Tangail & No & No & Normal & $\begin{array}{l}\text { Light } \\
\text { Green }\end{array}$ & No & No & Yes & No \\
\hline Canal-18 & Gazibari canal, Santosh, Tangail & Yes & Yes & Polluted & $\begin{array}{l}\text { Light } \\
\text { Green }\end{array}$ & No & No & No & No \\
\hline River-19 & Dholesshori river, Charabari, Tangail & Yes & Yes & Polluted & Gray & No & No & Yes & Yes \\
\hline River-20 & Lowhojong river, babystand, Tangail & Yes & Yes & Polluted & Turbid & No & No & Yes & No \\
\hline
\end{tabular}




\subsubsection{Dumping of Waste into the Sample Water Sources}

At present, the majority number of water reservoirs in Bangladesh are unsafe for human due to dumping of domestic, untreated industrial and municipal wastes [22]. Most of our study areas were being used as a dumping point of waste. In this study, $55 \%$ (11 out of 20 ) of the sampling point was polluted by directly dumping of waste (Table 1 ).

\subsubsection{Color of Water}

The color of water is the important premier indicators of water quality which indicates its suitability for human, fishes or others inhabitants of water. Water should be clear and colorless for acceptance to the general public. Discoloration in water can be attributed to the presence of iron or magnesium or to the presence of humus, peat molecules, plankton and the $\mathrm{pH}$ level of the water. The WHO has established the color levels below 15 true color unit (TCU) are acceptable for most consumers and the color above 15 TCU are detected by naked eye [23]. The color of the investigated water sources was observed visually. Out of twenty sampling stations, three sampling point were deep green in color, seven points were light green in color, three point were gray in color, four point were turbid and other three water bodies were brown in color (Table 1). Water rich in phytoplankton and other algae usually appears green, soil runoff produces gray colors, dissolved organic matter, such as humus, peat or decaying plant matter can produce brown color and presence of much clay and unnecessary inorganic substances in water causes turbid color [24].

\subsubsection{Usage of Sample Water Sources}

The most people of rural village of Bangladesh use wetland water for their daily purposes (washing, cooking, bathing etc.) due to unavailable of safe water sources [4]. In our study, sample water of study area neither used for the drinking nor cooking purposes due to presence of available safe water sources. Most cases, these waters were used to take bath and Oju (for holiness of prayer) by the people living around it. But water of pond-8, pond-12, Lake-16 and Canal-18 even were not suitable for bathing and Oju too (Table 1).

\subsubsection{Odor of the Water Samples}

Pure water (distilled) is odorless. The odor of the water indirectly indicates the severity of the pollution of water and the presence of toxic substances in it. The odor of the investigated sampling water was smelt by nose. About $85 \%$ of the sampling water had normal odor and $15 \%$ had bad odor during the June while $50 \%$ of the study point had bad odor during the February (Figure 2). Bad odor also results from discharging of domestic and industrial waste from the surrounding area and bacterial growth on water [25].

\subsection{6. $\mathrm{pH}$ of the Water}

$\mathrm{pH}$ is the vital factor of water which ensures the optimum environment for aquatic inhabitants. In our study, average $\mathrm{pH}$ values of the most of samples were more 


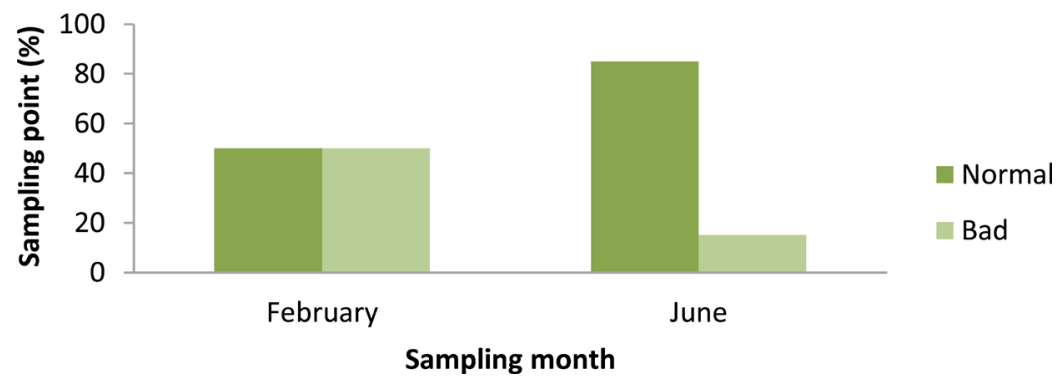

Figure 2. Odor of water at different sampling stations.

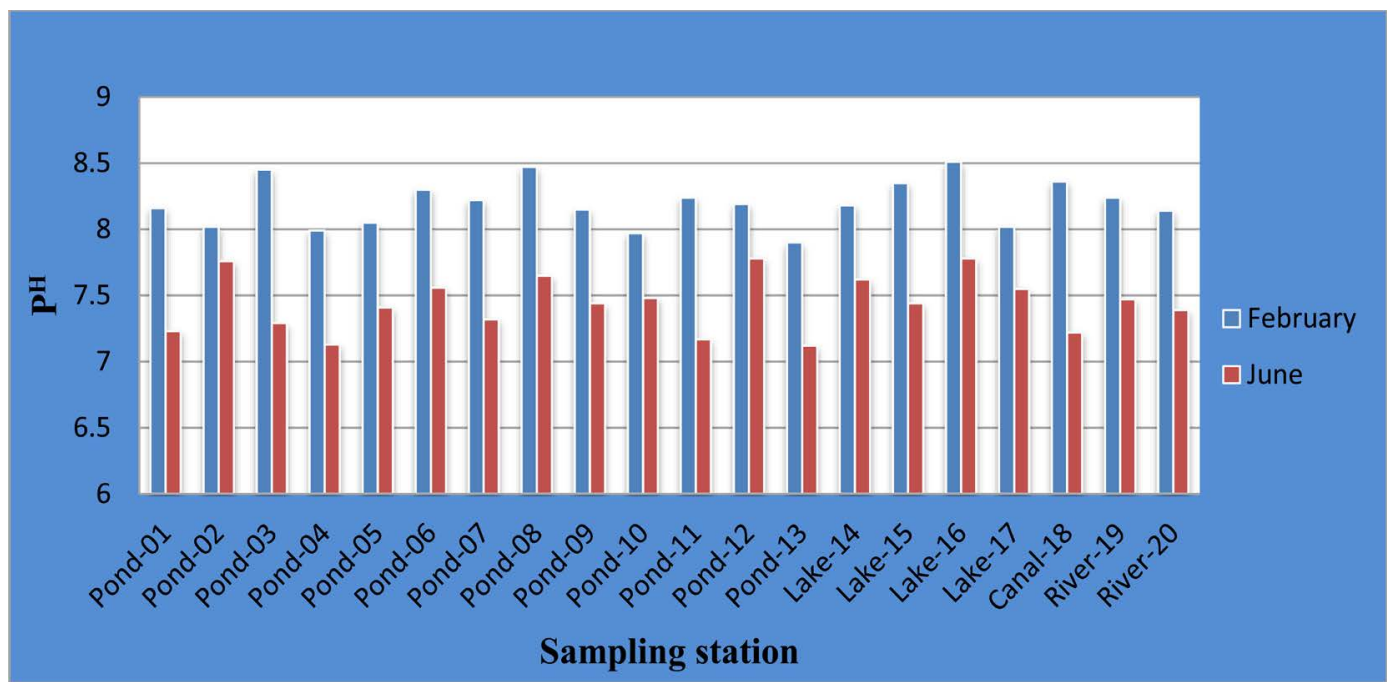

Figure 3. $\mathrm{pH}$ values of water at different sampling stations.

than 7 which is slightly alkaline. This might be due to inorganic sediments or domestic and agricultural wastes disposed in it. The $\mathrm{pH}$ values of samples ranged from 7.12 - 8.51 (Figure 3). $\mathrm{pH}$ range (7.5 - 8.4) is good for the growth of algae and range (6.0 - 7.2) is optimum for laying fish [26]. As per STOAS, pH values 4 or less and 12 or high cause death to most of the fish species, 6 to 8 is the range for good growth and reproduction, and $\mathrm{pH}$ as low as 5 or as high as 9 to 11 do not allow fishes to reproduce as well as cause slow growth [27]. The observed values reflect its suitability for aquatic life.

\subsubsection{Dissolved Oxygen (D0)}

Dissolved oxygen is essential for aquatic creature for respiration. Insufficient and imbalance DO may lead to cause of sudden death of these creature. In this study, values of DO at different sampling points were ranged from 2.8 to 6.1 $\mathrm{mg} / \mathrm{l}$. The highest DO value $6.1 \mathrm{mg} / \mathrm{l}$ was observed at two stations (pond-13 and lake-14) during June and the lowest DO $2.8 \mathrm{mg} / \mathrm{l}$ was also observed at pond-12 during February, which is not suitable for aquatic organisms (Figure 4). DO content should be above $6.0 \mathrm{mg} / \mathrm{l}$ for drinking water and more than $5.0 \mathrm{mg} / \mathrm{l}$ is suggested for fisheries, recreation and irrigation [28]. Except lake-14, all the sampling station had DO lower than $5 \mathrm{mg} / \mathrm{l}$. during the February. Study showed that $\mathrm{DO}$ of the sampling station was not suitable for fish production during the 


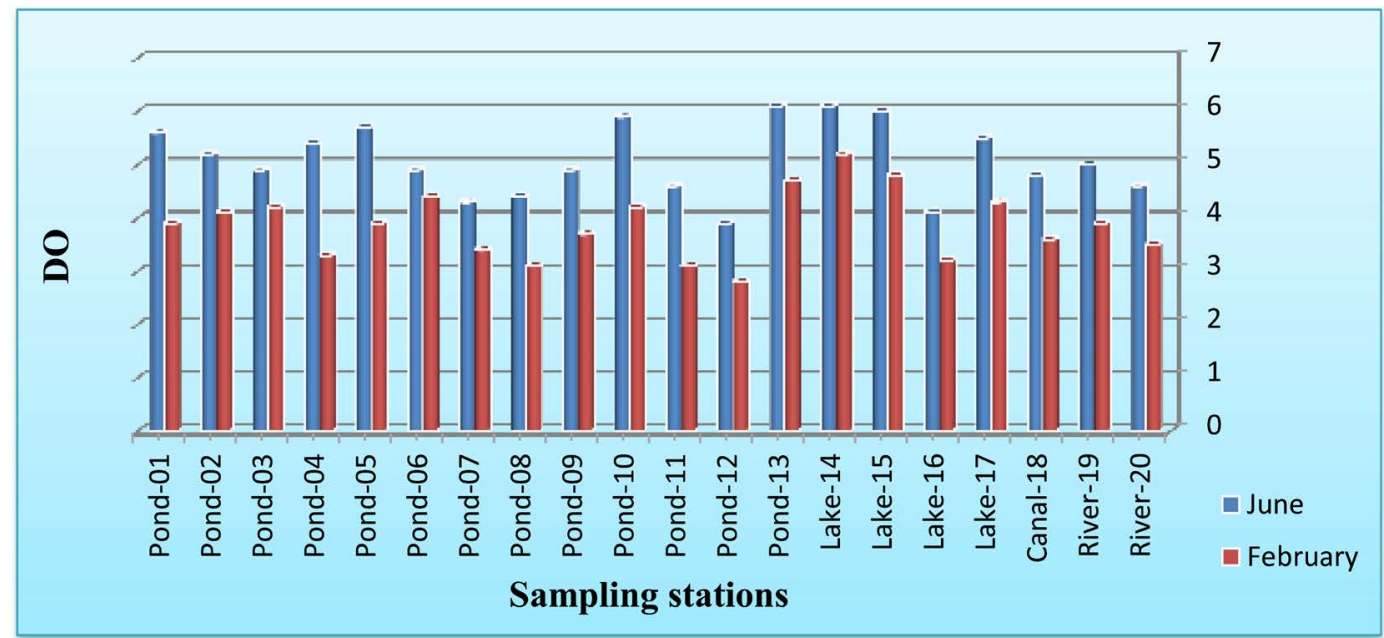

Figure 4. Values of DO at different sampling stations.

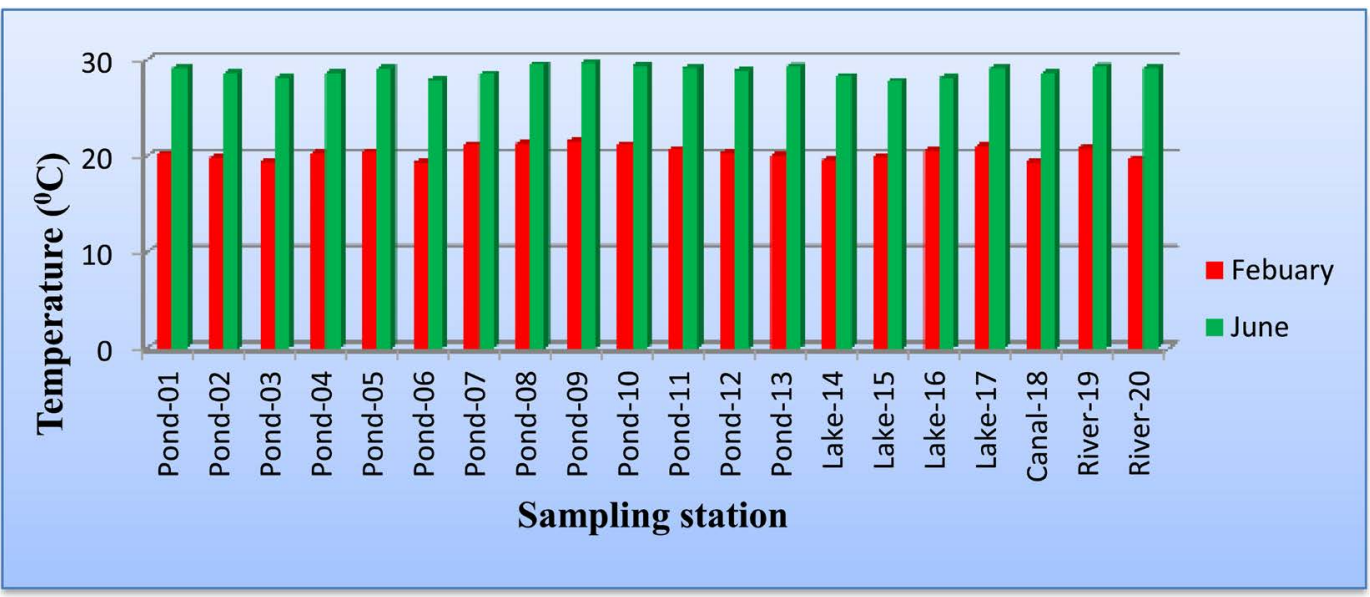

Figure 5. Temperature at different sampling stations.

month of February.

\subsubsection{Temperature}

According to the DoE standard, the ideal temperature of water for aquatic life is $20^{\circ} \mathrm{C}$ to $30^{\circ} \mathrm{C}$ [29]. The study showed that the range of temperature of all collected samples were $\left(19.4^{\circ} \mathrm{C}-21.5^{\circ} \mathrm{C}\right)$ during February and $\left(27.7^{\circ} \mathrm{C}-29.8^{\circ} \mathrm{C}\right)$ during June (Figure 5). The temperature range of June month fall within the DoE standard, but the temperature range of February month beneath the DoE standard. This is might be happened due to turbidity that prevent sunlight penetration, photo period which is directly related to the temperature, seasonality and flow rate.

\subsection{Opening of the Drain into the Water Bodies}

Most of the water bodies of the study area were polluted by effusion of drainage pollutants which carried different types of untreated wastes [30]. Drains were opened into $65 \%$ (13 out of 20 ) of the water body. Only $35 \%$ of the water bodies 
were not polluted by drainage waste (Figure 6).

\subsection{Direct Fecal Contamination through Open Latrine System}

Fecal contamination of surface water is a common phenomenon in Bangladesh. It occurs due to unsanitary or open latrine systems on the side of wetlands and that causes high rate of chronic, food and water borne diseases [31]. In our study, about $45 \%$ of the water bodies were fecal contaminated and $55 \%$ of water bodies were not contaminated with faeces (Figure 7). All the lakes, canals and rivers of the study area were fecal contaminated. All the ponds except pond-8, 9 were free from fecal contamination.

\subsection{Bacteriological Analysis}

\subsubsection{Total Coliform Count}

Present study showed that all of the water samples contained a variety of bacteria. Total coliforms which are used to evaluate the general quality of water, exceeded the WHO recommended acceptable limit in all of our study sample [32]. The range of total coliforms in all of collected samples was varied from $1.9 \times 10^{5} \mathrm{cfu} / 100 \mathrm{ml}$ to $6.3 \times 10^{23} \mathrm{cfu} / 100 \mathrm{ml}$. The recorded mean concentration of total coliform was $4.5 \times 10^{18} \mathrm{cfu} / 100 \mathrm{ml}$ during June and mean concentration was $4 \times 10^{22} \mathrm{cfu} / 100 \mathrm{ml}$ during February (Figure 8). The coliform counts at several points of the Buriganga river water was varied from $1.1 \times 10^{3}$ to $2.4 \times$ $10^{3} \mathrm{cfu} / 100 \mathrm{ml}$ [33]. The maximum mean concentration of total coliform was 13.81

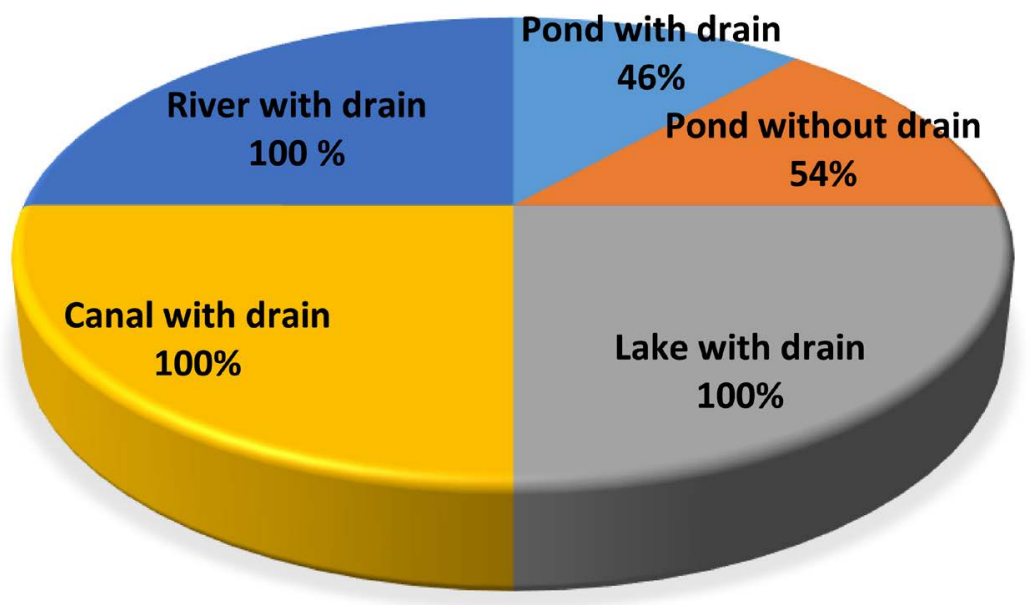

Figure 6. Opening of the drain into the water bodies.

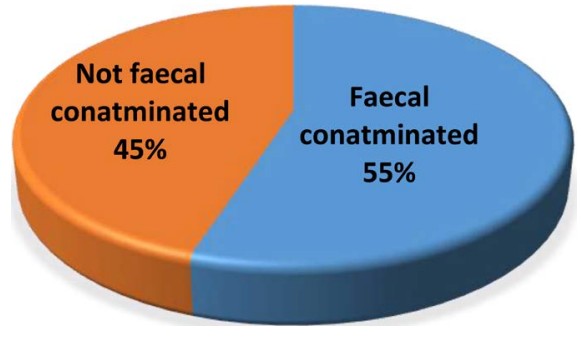

Figure 7. Contamination of water through open latrine system. 


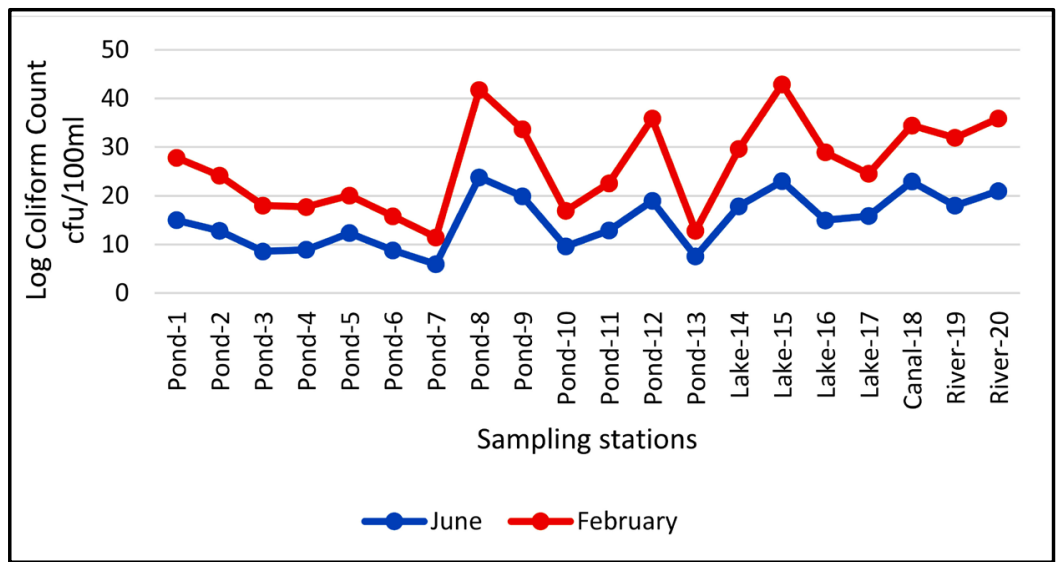

Figure 8. Total coliform bacterial count at different sampling stations.

$\times 10^{23} \mathrm{cfu} / 100 \mathrm{ml}$ during May and minimum mean concentration of total coliform was $12.7 \times 10^{8} \mathrm{cfu} / 100 \mathrm{ml}$ during April in Dhaleshwari River, Tangail [19]. The underlying causes of maximum load of bacteria in February were unhygienic conditions besides the water bodies, less amount of water present and the less rainfall. On the other hand there were sufficient amount of water present due to heavy rainfall, increase the amount of water that reduce the concentration of bacteria during the June.

\subsubsection{Fecal Coliform}

In our study, all of our samples were fecal coliform positive. Total coliform is a large collection of bacteria. Fecal coliform are types of total coliforms that exist in faeces. Fecal coliform bacteria are unlikely to cause illness, however their presence in drinking water may indicate the presence of disease-causing organisms [34].

\subsubsection{Escherichia coli Count}

The count of $E$. coli in our collected samples exceeded the EPA's recommended limit of E. coli [34]. E. coli is a subgroup of fecal coliform. The presence of $E$. coli in a drinking water sample usually indicates recent fecal contamination and means there is a greater risk that pathogens are present [35]. The range of E. coli in all of our collected samples was from $1.2 \times 10^{3} \mathrm{cfu} / 100 \mathrm{ml}$ to $2.1 \times 10^{12}$ $\mathrm{cfu} / 100 \mathrm{ml}$. The recorded mean concentration of $E$. coli was $2.2 \times 10^{7} \mathrm{cfu} / 100 \mathrm{ml}$ during February and mean concentration was $1.05 \times 10^{11} \mathrm{cfu} / 100 \mathrm{ml}$ during June (Figure 9). During June, monsoon rainwater runoff contaminated wetlands which causes the higher $E$. coli load in water.

\subsubsection{Salmonella spp. Count}

Typhoid fever is a severe systemic infection which is triggered by the ingestion of the bacteria Salmonella typhi and Salmonella paratyphi. Transmission of this disease is linked to contaminated food and water or via contact with fecal matter from acute or chronically infected individuals [36]. Among 20 water bodies, only 5 were contaminated with Salmonella spp. in February (mean concentration 


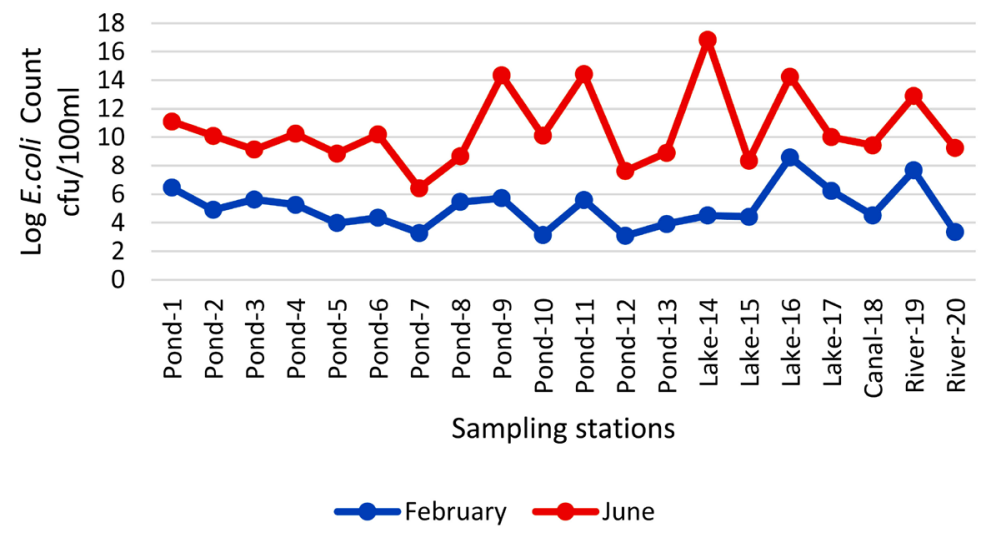

Figure 9. Total E. coli count at different sampling stations.

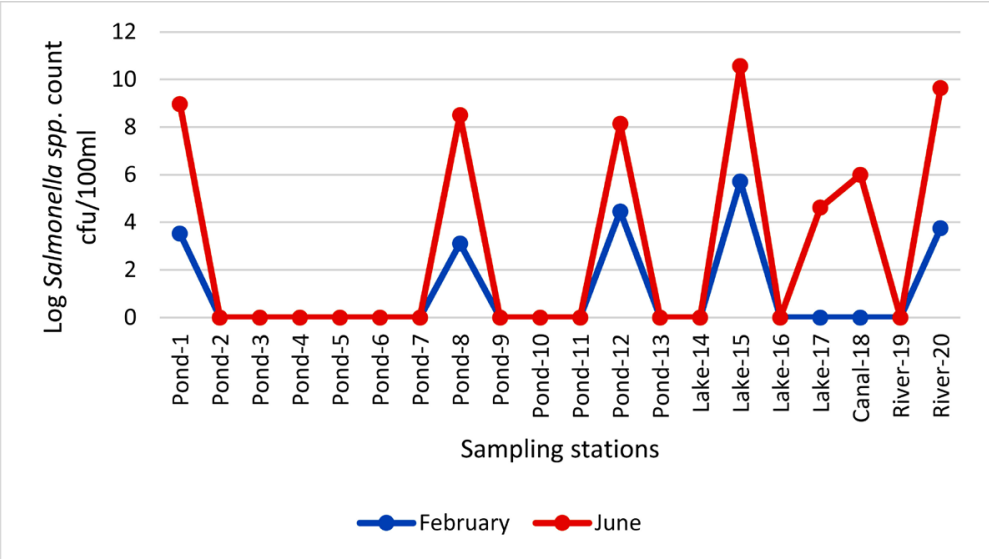

Figure 10. Salmonella spp. count at different sampling stations.

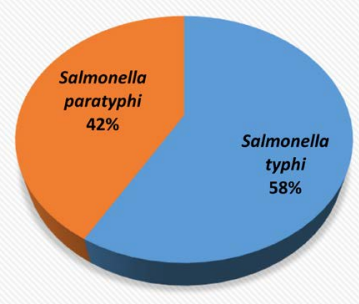

Figure 11. Distribution of Salmonella spp. at contaminated water samples.

$1.1 \times 10^{5} \mathrm{cfu} / 100 \mathrm{ml}$ ) and 7 water bodies were contaminated in June (mean concentration $3.4 \times 10^{5} \mathrm{cfu} / 100 \mathrm{ml}$ ) (Figure 10). Among that contaminated water bodies, about 58\% were contaminated with Salmonella typhi and $42 \%$ were contaminated with Salmonella paratyphi (Figure 11). Salmonella count in water showed peak during June and the prevalence of Salmonella typhi is higher than Salmonella paratyphi in Bangladesh [37].

\subsubsection{Vibrio spp. Count}

Vibrio cholerae caused cholera which is a major public health problem in developing countries like Bangladesh. Vibrio cholera is a waterborne pathogen and 
transmission of this bacteria is occurred through mainly contaminated aquatic sources or the faeces of an infected person [38]. Among 20 water bodies, only 8 were contaminated by Vibrio spp. in February (mean concentration $8.6 \times$ $10^{5} \mathrm{cfu} / 100 \mathrm{ml}$ ) and 11 water bodies were contaminated in June (mean concentration $1.1 \times 10^{8} \mathrm{cfu} / 100 \mathrm{ml}$ ) (Figure 12). The ingestion of approximately $10^{4}-10^{6}$ Vibrio cholerae organisms is likely to produce clinical cholera [39]. The load of Vibrio cholerae in our sample during both February and June are able to cause cholera outbreak. Among that contaminated water bodies, about $87 \%$ were contaminated by Vibrio cholerae and 13\% were contaminated by Vibrio parahaemolytics (Figure 13). In Bangladesh, the outbreaks of cholera is mainly caused by Vibrio cholerae $\mathrm{O} 139$ and Vibrio cholerae o1 replaces the other with time in an endemic area or during a prolonged outbreak [40].

\subsubsection{Shigella spp. Count}

Shigella spp. causes bacillary dysentery that can be transmitted by contaminated food and water. Research has shown a number of large waterborne outbreaks of shigellosis over the past years [41]. Among 20 water bodies, only 6 were contaminated with Shigella spp. in February (mean concentration $8 \times 10^{4} \mathrm{cfu} / 100 \mathrm{ml}$ ) and 9 water bodies were contaminated in June (mean concentration $3.7 \times 10^{7}$ cfu/100ml) (Figure 14). The load of Shigella spp. in study samples are enough to

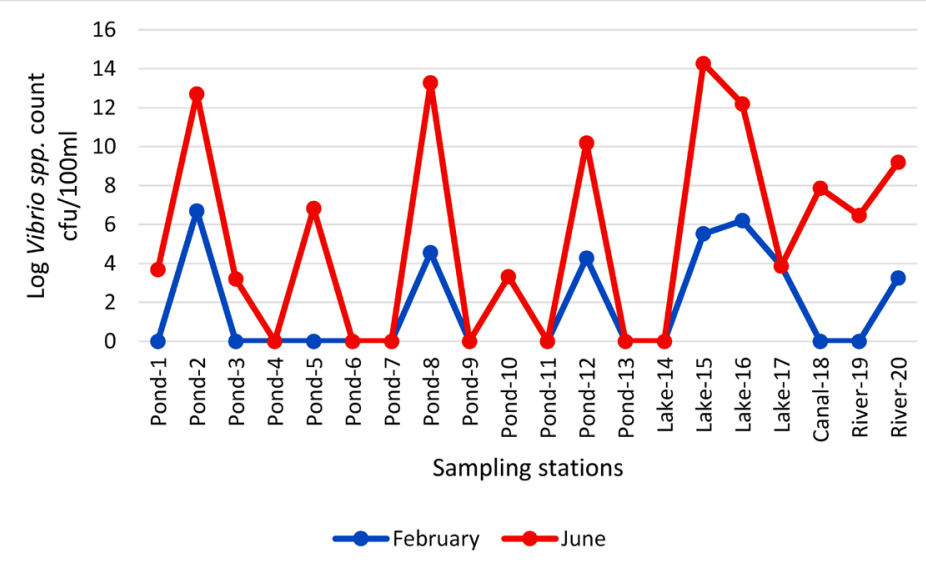

Figure 12. Vibrio spp. load at different sampling stations.

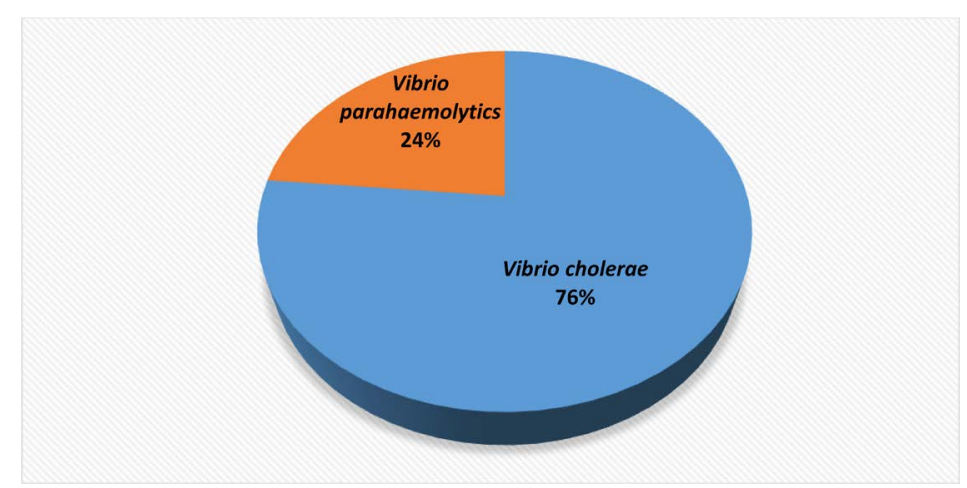

Figure 13. Distributions of Vibrio spp. at different sampling stations. 


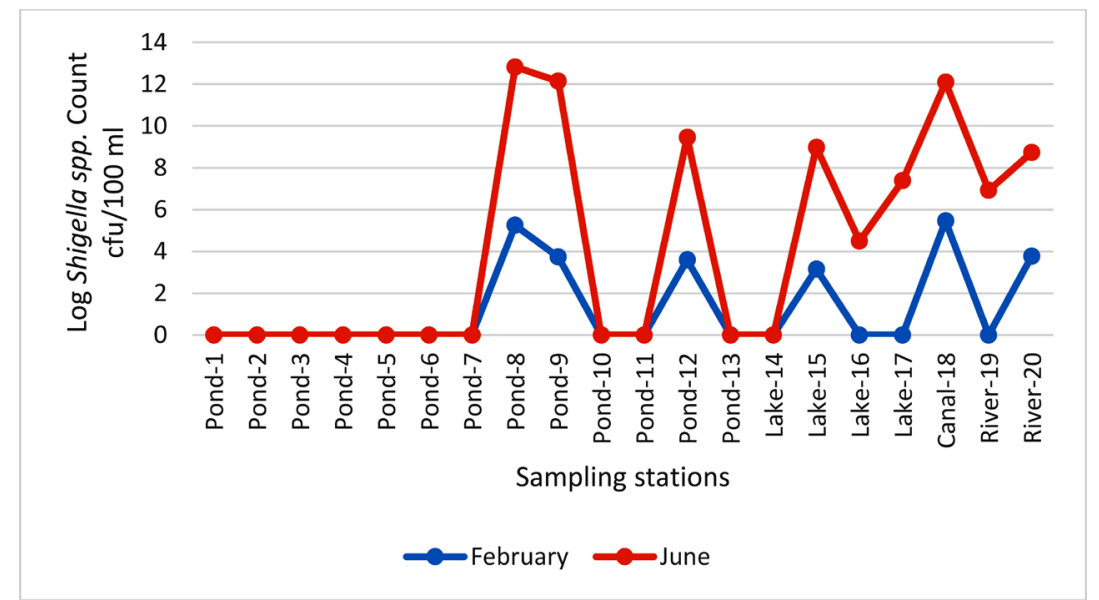

Figure 14. Shigella spp. load at different sampling stations.

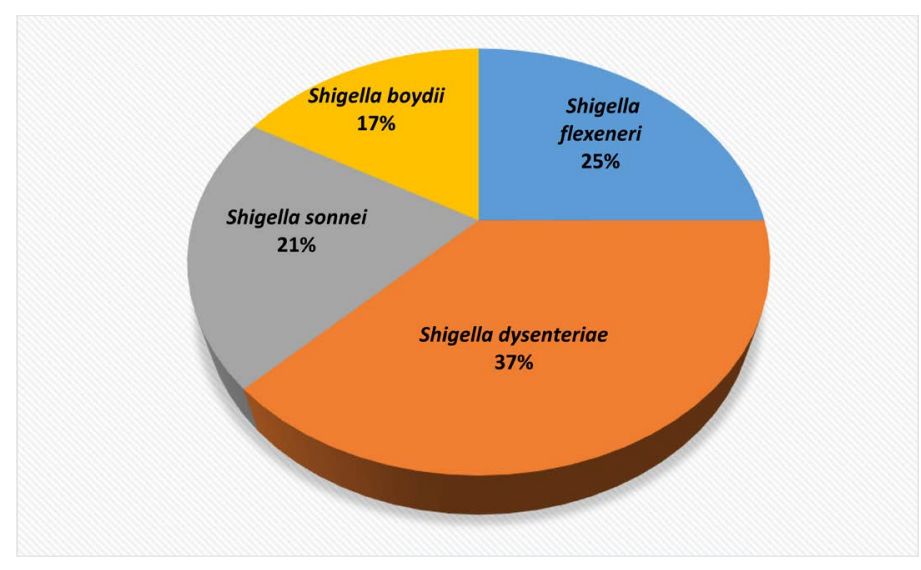

Figure 15. Distributions of Shigella spp. at different sampling stations.

cause shigellosis [42]. Among different serotypes of Shigella spp., Shigella $d y$ senteriae were the dominating one. Among that contaminated water bodies, about $37 \%$ were contaminated by Shigella dysenteriae, $25 \%$ were contaminated by Shigella flexneri, $21 \%$ by Shigella sonnei and $17 \%$ by Shigella boydii (Figure 15). In Bangladesh two predominant Shigella spp., Shigella flexneri was isolated most frequently during August - January and Shigella dysenteriae during June to July [43].

\subsection{Correlation Matrix among Bacteriological and Physiochemical Parameters of Different Sampling Stations}

Karl Pearson's correlation coefficient along with their significant test was used to correlate among parameters to build up a matrix. This study showed that cattle wash and dumping of waste directly pollute the water and change the color and odor of the water. Opening of the drain into water sources and direct fecal contamination through opening of latrine indirectly polluted the water (Table 2). Total coliform count was positively correlated with $\mathrm{pH}(\mathrm{r}=0.385 ; p<0.01)$ and temperature $(\mathrm{r}=0.259 ; p<0.05)$ and negatively correlated with DO. Otherwise, total $E$. coli. count was positively correlated with DO $(\mathrm{r}=0.441 ; p<0.01)$. Salmonella 
Table 2. Correlation Analysis (Physical conditions of the ponds and waters).

\begin{tabular}{|c|c|c|c|c|c|c|c|}
\hline Parameters & $\begin{array}{l}\text { Odor of } \\
\text { water }\end{array}$ & $\begin{array}{l}\text { Cattle } \\
\text { wash }\end{array}$ & $\begin{array}{l}\text { Dumping of } \\
\text { waste }\end{array}$ & $\begin{array}{l}\text { Water } \\
\text { type }\end{array}$ & $\begin{array}{l}\text { Color of } \\
\text { water }\end{array}$ & $\begin{array}{l}\text { Opening of the } \\
\text { drain into the pond }\end{array}$ & $\begin{array}{l}\text { Direct fecal contamination } \\
\text { through opening of latrine }\end{array}$ \\
\hline Odor of water & 1 & & & & & & \\
\hline Cattle wash & 0.437 & 1 & & & & & \\
\hline Dumping of waste & $0.810^{* *}$ & $0.522^{*}$ & 1 & & & & \\
\hline Water type & $0.895^{* *}$ & $0.577^{\star *}$ & $0.905^{* *}$ & 1 & & & \\
\hline Color of water & $0.639^{* *}$ & 0.37 & $0.499^{*}$ & $0.641^{\star *}$ & 1 & & \\
\hline Opening of the drain into the pond & $-0.512^{*}$ & -0.424 & $-0.601^{\star *}$ & $-0.524^{*}$ & -0.134 & 1 & \\
\hline Direct fecal contamination & -0.436 & $-0.638^{\star *}$ & $-0.616^{* *}$ & $-0.503^{*}$ & -0.225 & $0.664^{* *}$ & 1 \\
\hline
\end{tabular}

Table 3. Correlation Analysis (Internal conditions).

\begin{tabular}{|c|c|c|c|c|c|c|c|c|}
\hline Parameters & $\mathrm{pH}$ & DO & Temperature & Total coliform count & Total E. coli count & Salmonella spp. & Vibrio spp. & Shigella spp. \\
\hline $\mathrm{pH}$ & 1 & & & & & & & \\
\hline DO & $-0.375^{\star}$ & 1 & & & & & & \\
\hline Temperature & $-0.200^{* *}$ & -0.249 & 1 & & & & & \\
\hline Total coliform count & $0.385^{* *}$ & -0.234 & $0.259^{*}$ & 1 & & & & \\
\hline Total E. coli count & $0.127^{\star}$ & $0.441^{* *}$ & -0.262 & -0.068 & 1 & & & \\
\hline Salmonella spp. & 0.319 & $-0.171^{*}$ & -0.427 & -0.190 & -0.045 & 1 & & \\
\hline Vibrio spp. & -0.099 & $0.038^{\star *}$ & $0.413^{*}$ & -0.143 & $0.451^{* *}$ & -0.325 & 1 & \\
\hline Shigella spp. & $0.263^{\star *}$ & 0.290 & $-0.292^{*}$ & -0.107 & -0.182 & -0.068 & -0.272 & 1 \\
\hline
\end{tabular}

spp. showed negative correlation with DO and temperature; and positive correlation with $\mathrm{pH}$. Vibrio spp. was significantly correlated with DO $(\mathrm{r}=0.038 ; p<$ $0.01)$ and $E$. coli count $(\mathrm{r}=0.451 ; p<0.01)$. Shigella spp. showed positive correlation with $\mathrm{DO}$ and $\mathrm{pH}$; and negative correlation with temperature. Environmental parameters such as temperature, $\mathrm{pH}$ and dissolved oxygen play a vital role in various bacterial count in water (Table 3) [44]. The decrease trend $(\mathrm{r}=$ $-0.707 ; p<0.05)$ in total coliform bacteria with the increase of DO and increase trend with the increase of temperature $(\mathrm{r}=0.755 ; p<0.05)$ [19] which is similar to our study result. One-way ANOVA study was conducted to know the mean differences of the quantity of parameters among different times of sampling (Table 4). The result revealed that the $p$-value is $0.00(<0.05)$ for the parameters of $\mathrm{pH}, \mathrm{DO}$ and Temperature, which implies that the quantity of these parameters significantly differ at different times of taking the samples. The result also represented that the $\mathrm{p}$-values are greater than 0.05 for the parameters of total coliform count, total E. coli count, Salmonella spp., Vibrio spp. and Shigella spp., which implies that the quantity of these parameters remain the same for all the time of taking the samples.

\subsection{Prevalence of Waterborne Diseases at the Study Area}

Waterborne diseases are the major burden in the study area. Most of these water 
Table 4. Multiple comparison among parameters.

\begin{tabular}{|c|c|c|c|c|c|c|}
\hline Parameters & Source of Variation & SS & $d f$ & $M S$ & $F$ & $P$-value \\
\hline \multirow{2}{*}{$\mathrm{P}^{\mathrm{H}}$} & Between Groups & 5.70025 & 2 & 2.850125 & 87.35851 & 0.00 \\
\hline & Within Groups & 1.85966 & 57 & 0.032626 & & \\
\hline \multirow{2}{*}{ DO } & Between Groups & 15.129 & 2 & 7.5645 & 18.23773 & 0.00 \\
\hline & Within Groups & 23.642 & 57 & 0.414772 & & \\
\hline \multirow[t]{2}{*}{ Temperature } & Between Groups & 721.6503 & 2 & 360.8251 & 970.4234 & 0.00 \\
\hline & Within Groups & 21.19388 & 57 & 0.371822 & & \\
\hline \multirow[t]{2}{*}{ Total Coliform count } & Between Groups & $1.64 \mathrm{E}+46$ & 2 & $8.22 \mathrm{E}+45$ & 0.985578 & 0.38 \\
\hline & Within Groups & $4.75 \mathrm{E}+47$ & 57 & $8.34 \mathrm{E}+45$ & & \\
\hline \multirow[t]{2}{*}{ Total E. coli count } & Between Groups & $1.1 \mathrm{E}+23$ & 2 & $5.52 \mathrm{E}+22$ & 0.6004 & 0.55 \\
\hline & Within Groups & $5.24 \mathrm{E}+24$ & 57 & $9.19 \mathrm{E}+22$ & & \\
\hline \multirow[t]{2}{*}{ Salmonella spp. } & Between Groups & $1.59 \mathrm{E}+11$ & 2 & $7.97 \mathrm{E}+10$ & 0.736115 & 0.49 \\
\hline & Within Groups & $1.73 \mathrm{E}+12$ & 16 & $1.08 \mathrm{E}+11$ & & \\
\hline \multirow[t]{2}{*}{ Vibrio spp. } & Between Groups & $5.37 \mathrm{E}+16$ & 2 & $2.68 \mathrm{E}+16$ & 1.30015 & 0.29 \\
\hline & Within Groups & $5.99 \mathrm{E}+17$ & 29 & $2.06 \mathrm{E}+16$ & & \\
\hline \multirow[t]{2}{*}{ Shigella spp. } & Between Groups & $5 \mathrm{E}+15$ & 2 & $2.5 \mathrm{E}+15$ & 0.736673 & 0.49 \\
\hline & Within Groups & $7.13 \mathrm{E}+16$ & 21 & $3.39 \mathrm{E}+15$ & & \\
\hline
\end{tabular}

Table 5. Impact of waterborne diseases on public health.

\begin{tabular}{|c|c|c|c|c|c|c|}
\hline Diseases & $\begin{array}{l}\text { Clear concept about } \\
\text { reasons and treatment }\end{array}$ & $\begin{array}{l}\text { Suffering from a } \\
\text { long time }\end{array}$ & $\begin{array}{l}\text { Number of } \\
\text { respondents } \\
\text { frequently }\end{array}$ & $\begin{array}{l}\text { Affected within last } 3 \\
\text { months }\end{array}$ & $\begin{array}{c}\text { Took antibiotic } \\
\text { dosages }\end{array}$ & $\begin{array}{c}\text { Efficiency of antibiotic } \\
\text { dosage }(\%)\end{array}$ \\
\hline Diarrhea & 290 & 11 & 14 & 15 & 13 & 30.8 \\
\hline Dysentery & 211 & 8 & 6 & 20 & 19 & 26.3 \\
\hline Cholera & 76 & - & 2 & 7 & 5 & 40 \\
\hline Typhoid & 145 & - & - & 17 & 15 & 47.2 \\
\hline Hepatitis & 232 & - & - & 6 & 3 & 66.6 \\
\hline Botulism & 37 & - & 5 & - & & \\
\hline Scabies & 145 & 3 & 12 & 2 & 1 & 100 \\
\hline Skin diseases & 229 & 27 & 19 & 9 & 8 & 50 \\
\hline Skin cancer & 172 & - & - & - & - & \\
\hline Dad & 257 & 2 & - & 2 & 1 & 100 \\
\hline Itching & 315 & 13 & 26 & 15 & 10 & 35 \\
\hline
\end{tabular}

borne diseases are attributed to the contaminated water that contains various infectious pathogens. Further, few people have been found in the study area who use proper water purification systems are free from these waterborne diseases.

To investigate the impact of contaminated water source on surroundings public health, we took 20 persons from each sampling site and total respondents were 400 people (Table 5). Most of the people had clear concept about these 
waterborne diseases. Very little number of people were suffering from those diseases from long time. Some people were affected with these waterborne diseases within last three months and took antibiotic dosage for treatment. But the efficiency of these antibiotics were not satisfactory and which also indicates the occurrence of antibiotic resistance.

\subsection{Antibiotic Resistance Pattern of Waterborne Pathogen}

In antibiogram study, most of the available waterborne pathogens in Bangladesh were found to be antibiotic resistance. Almost all waterborne bacteria in our study, were mostly resistance to Penicillin. Shigella spp. was highly resistance to Ampicillin (86\%) and highly sensitive to Ciprofloxacin (66\%) (Figure 16). Salmonella spp. was highly resistance to Amoxicillin (66\%) and highly sensitive to Gentamicin (53\%) (Figure 17). Vibrio spp. was highly resistance to Ampicillin (93\%) and highly sensitive to Gentamicin (40\%) (Figure 18). E. coli was highly resistance to Erythromycin (53\%), Ampicillin (53\%) and highly sensitive to Gentamicin (80\%), Ciprofloxacin (80\%) (Figure 19). In Bangladesh, problem with waterborne diseases and dissemination of antibiotic resistance bacteria through surface water exacerbates the situation [45].

\section{Conclusion}

Surface water is vital for the daily activities of life which is polluted by household, municipal, industrial and agricultural wastes. The quality of surface water may impact on the incidence of various water-borne infectious diseases. The present study revealed that the physiochemical and bacterial quality of the water sources were out of the acceptable limit of WHO and hazardous for drinking, domestic purposes and fish culture due to fecal pollution. Low dissolved oxygen and higher $\mathrm{pH}$ values indicate that organic and chemical wastes polluted surface water bodies. Microbial colonization was low in February and increased in June due to rainfall. The antibiotic resistant bacteria in surface water resources poses

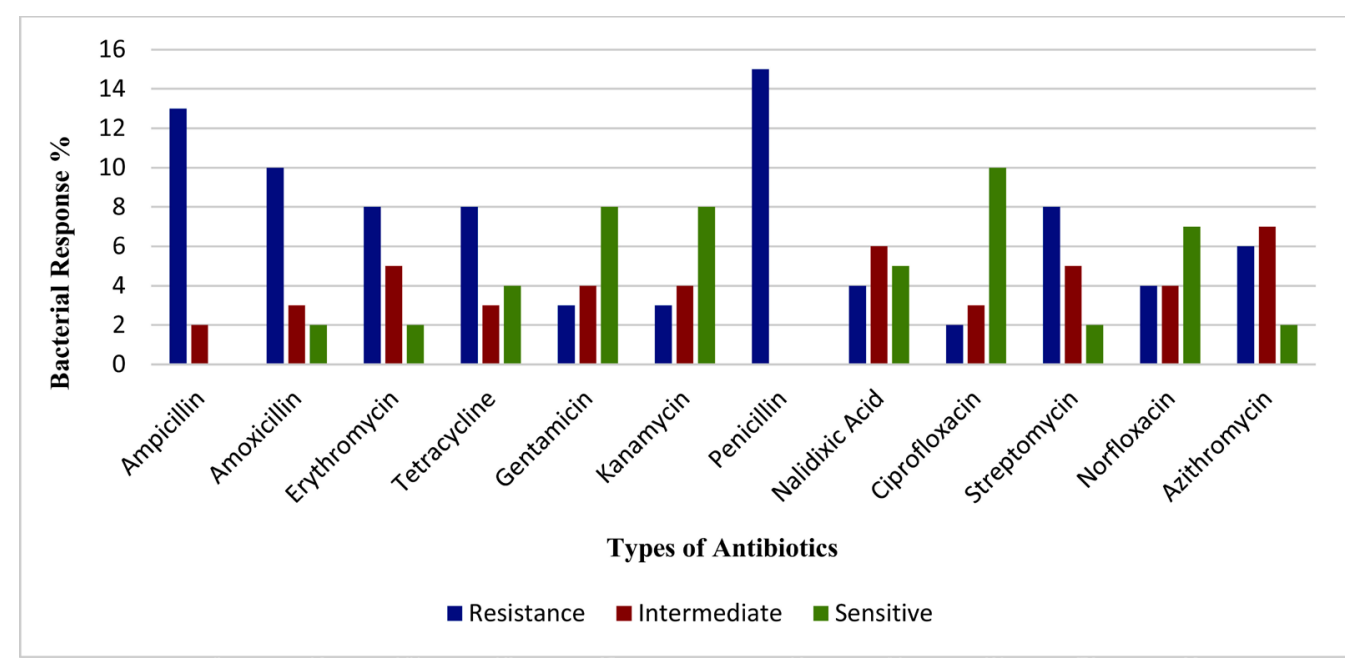

Figure 16. Antibiotic resistance pattern of Shigella spp. 


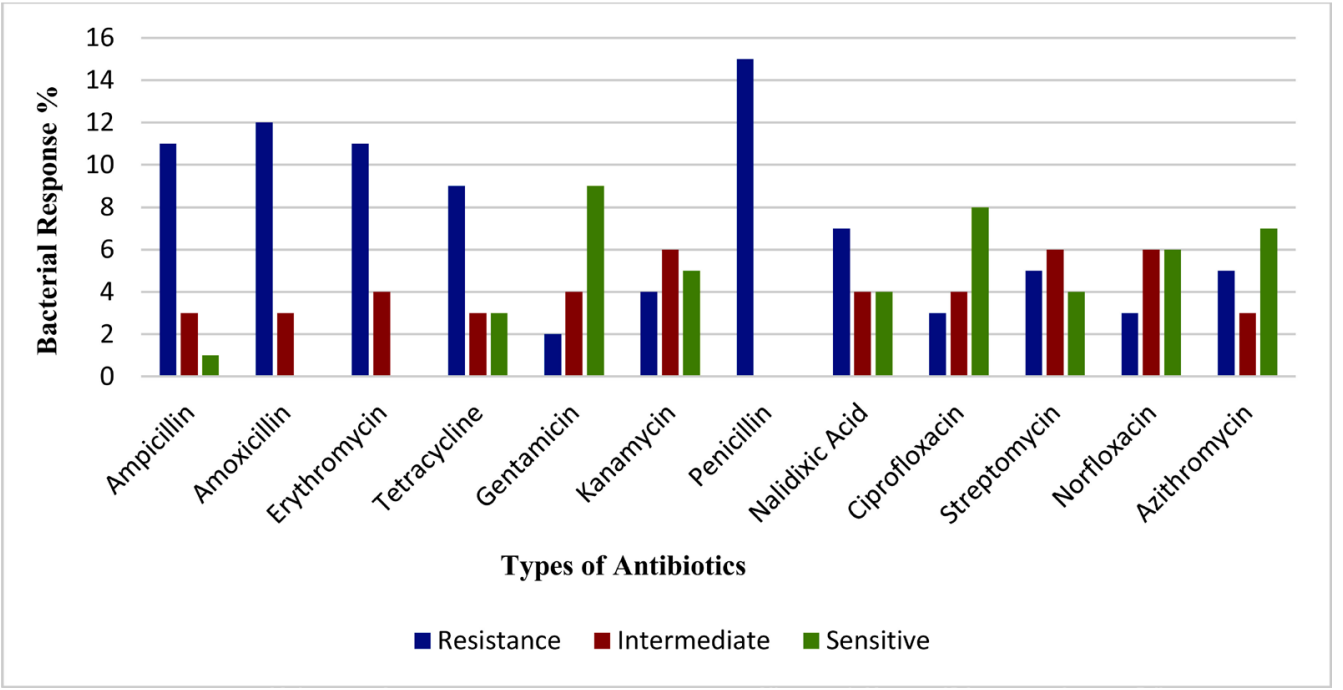

Figure 17. Antibiotic resistance pattern of Salmonella spp.

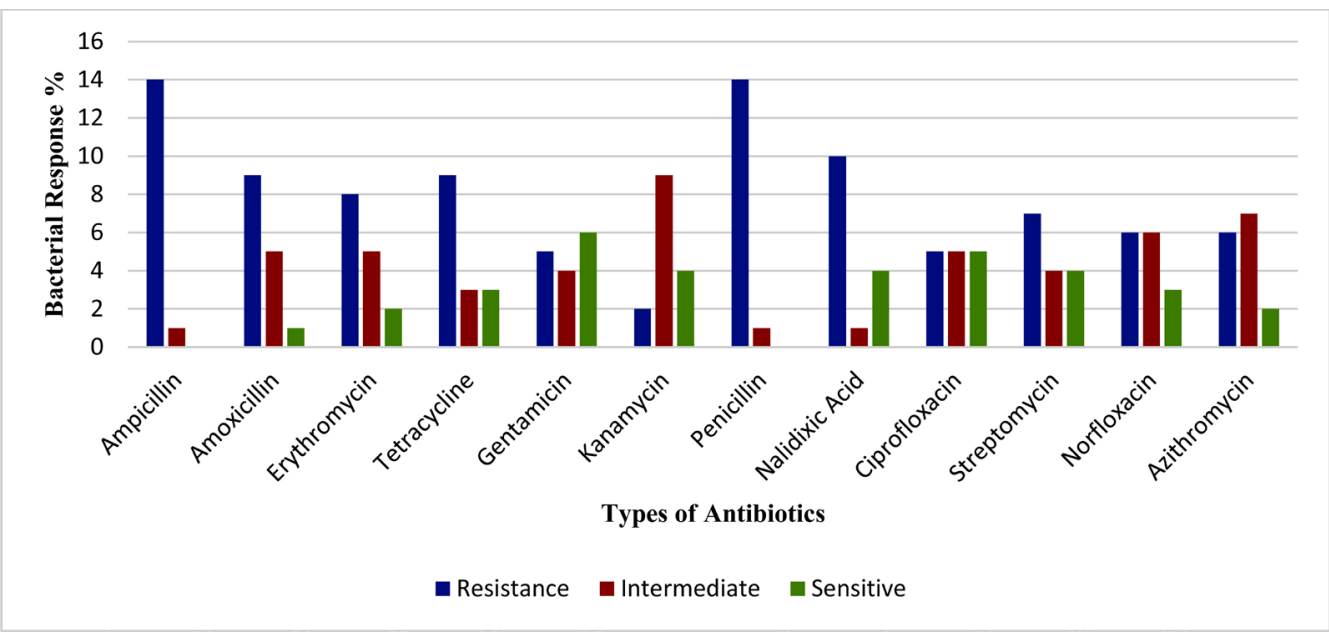

Figure 18. Antibiotic resistance pattern of Vibrio spp.

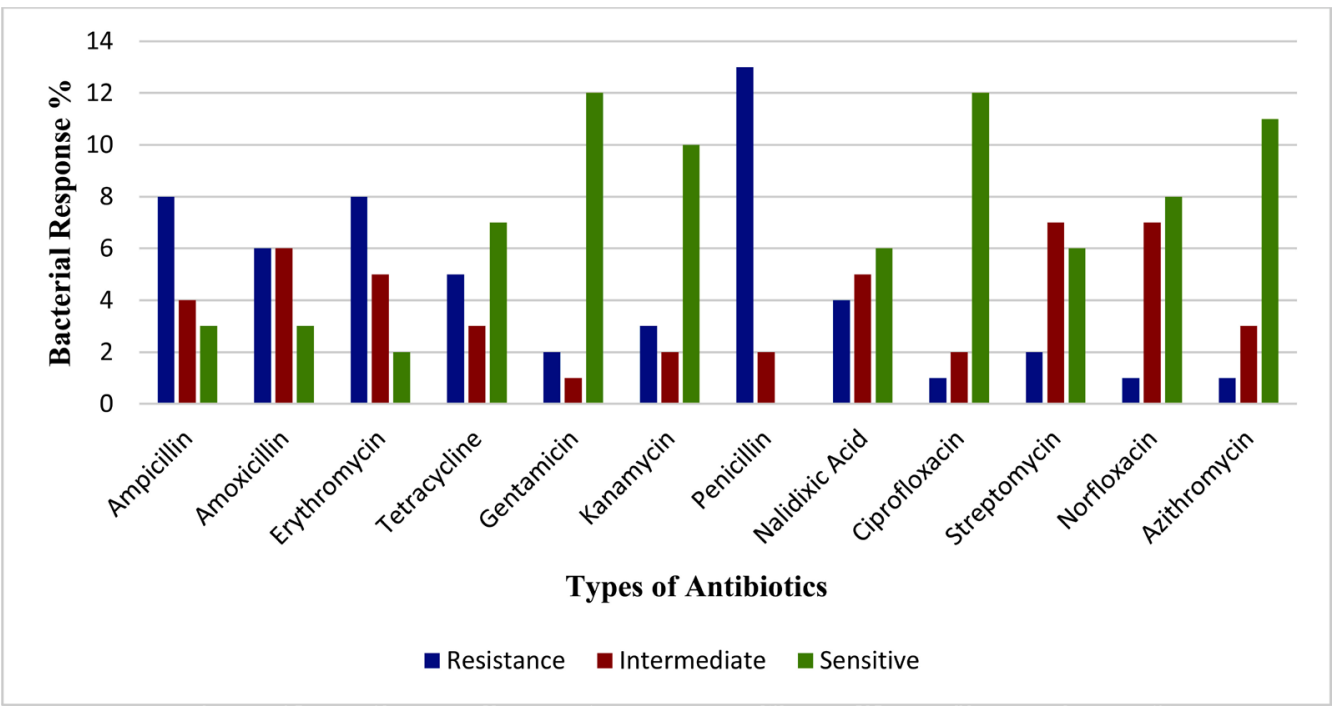

Figure 19. Antibiotic resistance pattern of E. coli. 
a serious public health treat and the source of resistant bacteria and responsible genes for resistance should be explored. From this study it can be recommended that the government authorities should establish protocols to monitor water quality in the Tangail district communities and develop awareness programs to inform the communities about status of the water quality to protect people from water-borne infection diseases.

\section{References}

[1] Brum, G. and McKane, L. (1994) Biology: Exploring Life.

[2] Dara, S. (1993) A Textbook of Environmental Chemistry and Pollution Control. S. Chand, New Delhi.

[3] Gleick, P.H. (1993) Water in Crisis: A Guide to the Worlds Fresh Water Resources.

[4] Byomkesh, T., Nakagoshi, N. and Shahedur, R.M. (2009) State and Management of Wetlands in Bangladesh. Landscape and Ecological Engineering, 5, 81. https://doi.org/10.1007/s11355-008-0052-5

[5] Organization, W.H. (2007) Economic and Health Effects of Increasing Coverage of Low Cost Household Drinking-Water Supply and Sanitation Interventions to Countries Off-Track to Meet MDG Target 10: Background Document to the "Human Development Report 2006".

[6] Goel, P. (2006) Water Pollution: Causes, Effects and Control. New Age International.

[7] Mobin, M., et al. (2015) Analysis of Physicochemical Properties of the Turag River Water, Tongi, Gazipur in Bangladesh. Journal of Environmental Science and Natural Resources, 7, 27-33. https://doi.org/10.3329/jesnr.v7i1.22140

[8] Alam, M.J., et al. (2007) Water Quality Parameters along Rivers. International Journal of Environmental Science \& Technology, 4, 159-167. https://doi.org/10.1007/BF03325974

[9] Saha, M.L., et al. (2012) Bacteriological and Physicochemical Water Quality of Four Ponds of Dhaka Metropolis. Bangladesh Journal of Botany, 41, 55-60. https://doi.org/10.3329/bjb.v41i1.11083

[10] Tallon, P., et al. (2005) Microbial Indicators of Fecal Contamination in Water: A Current Perspective. Water, Air, and Soil Pollution, 166, 139-166. https://doi.org/10.1007/s11270-005-7905-4

[11] Moe, C.L. and Rheingans, R.D. (2006) Global Challenges in Water, Sanitation and Health. Journal of Water and Health, 4, 41-57.

[12] Talukdar, P.K., et al. (2013) Antimicrobial Resistance, Virulence Factors and Genetic Diversity of Escherichia coli Isolates from Household Water Supply in Dhaka, Bangladesh. PLOS ONE, 8, e61090. https://doi.org/10.1371/journal.pone.0061090

[13] Sack, R.B., et al. (1997) Antimicrobial Resistance in Organisms Causing Diarrheal Disease. Clinical Infectious Diseases, 24, S102-S105.

[14] Balan, I., Shivakumar, M. and Kumar, P.M. (2012) An Assessment of Groundwater Quality using Water Quality Index in Chennai, Tamil Nadu, India. Chronicles of Young Scientists, 3, 146-146. https://doi.org/10.4103/2229-5186.98688

[15] Prescott, H. and Harley, J. (2002) Klein. Microbiology.

[16] Auer, M.T. and Niehaus, S.L. (1993) Modeling Fecal Coliform Bacteria-I. Field and Laboratory Determination of Loss Kinetics. Water Research, 27, 693-701. 
https://doi.org/10.1016/0043-1354(93)90179-L

[17] Kabir, S.L., et al. (2015) Safety Assessment of Tubewell Water at Fulbaria pourasava in Mymensingh District of Bangladesh.

[18] Ngwa, N.R. and Chrysanthus, N. (2013) Bacteriological Analysis of Well Water Sources in the Bambui Student Residential Area. Journal of Water Resource and Protection, 5, 1013. https://doi.org/10.4236/jwarp.2013.511106

[19] Real, K.H., et al. (2017) Assessment of Water Quality and Microbial Load of Dhaleshwari River Tangail, Bangladesh. Advances in Microbiology, 7, 523-533. https://doi.org/10.4236/aim.2017.76041

[20] Al-Salauddin, A.S., et al. (2015) Isolation, Identification, and Antibiogram Studies of Salmonella Species and Escherichia coli from Boiler Meat in Some Selected Areas of Bangladesh.

[21] Roche, L.M., et al. (2013) Water Quality Conditions Associated with Cattle Grazing and Recreation on National Forest Lands. PLoS ONE, 8, e68127. https://doi.org/10.1371/journal.pone.0068127

[22] Reza, A. and Yousuf, T.B. (2016) Impacts of Waste Dumping on Water Quality in the Buriganga River, Bangladesh and Possible Mitigation Measures. Journal of the Environment, 11, 35-40.

[23] Organization, W.H. (2004) Guidelines for Drinking-Water Quality. Vol. 1, World Health Organization.

[24] Team, C.W. (2004) Color of Water Fact Sheet. Citeseer.

[25] Volk, C., et al. (2002) Monitoring Dissolved Organic Carbon in Surface and Drinking Waters. Journal of Environmental Monitoring, 4, 43-47. https://doi.org/10.1039/b107768f

[26] Meade, J.W. (2012) Aquaculture Management. Springer Science \& Business Media.

[27] Kawasaki, J. (2002) Animal Science and Livestock Production. Books in Library and Information Science, 135-156. https://doi.org/10.1201/9780203909119.ch5

[28] Lucy, R., Huda, M. and Islam, S. (2016) Comparative Study on Physicochemical and Biological Parameters of Water among Fish Culture and Reconstructed Pond at Jahangirnagar University Campus, Bangladesh. Journal of Environmental Science and Natural Resources, 9, 1-7. https://doi.org/10.3329/jesnr.v9i1.30248

[29] Bhaumik, U., Das, P. and Paria, T. (2006) Impact of Plankton Structure on Primary Productivity in Two Beels of West Bengal, India. Bangladesh Journal of Fisheries Research, 10, 1-11.

[30] Nagano, Y., et al. (2014) Characterization of Water Pollution in Drainage Networks using Continuous Monitoring Data in the Citadel Area of Hue City, Vietnam. Water Science and Technology, 70, 612-619. https://doi.org/10.2166/wst.2014.243

[31] Knappett, P.S., et al. (2011) Impact of Population and Latrines on Fecal Contamination of Ponds in Rural Bangladesh. Science of the Total Environment, 409, 3174-3182. https://doi.org/10.1016/j.scitotenv.2011.04.043

[32] Edition, F. (2011) Guidelines for Drinking-Water Quality. WHO Chronicle, 38, 104-108.

[33] Hasan, M.M., et al. (2006) Load of HeteLoad of Heterotrophicrotrophic and Nitrifying Bacteria in the Sewage Lagoon and the Receiving River Buriganga. Bangladesh Journal of Microbiology, 23, 93-97.

[34] Dufour, A. (1984) Health Effects Criteria for Fresh Recreational Waters. EPA Document Number EPA-600. 
[35] Godfree, A., Kay, D. and Wyer, M. (1997) Fecal Streptococci as Indicators of Fecal Contamination in Water. Journal of Applied Microbiology, 83, 110-119. https://doi.org/10.1046/j.1365-2672.83.s1.12.x

[36] Parry, C.M. (2004) The Treatment of Multidrug-Resistant and Nalidixic Acid-Resistant Typhoid Fever in Viet Nam. Transactions of the Royal Society of Tropical Medicine and Hygiene, 98, 413-422. https://doi.org/10.1016/j.trstmh.2003.10.014

[37] Afroz, H., Hossain, M.M. and Fakruddin, M. (2014) A 6-Year Retrospective Study of Bloodstream Salmonella Infection and Antibiotic Susceptibility of Salmonella enterica Serovar Typhi and Paratyphi in a Tertiary Care Hospital in Dhaka, Bangladesh. Tzu Chi Medical Journal, 26, 73-78. https://doi.org/10.1016/j.tcmj.2014.05.006

[38] Islam, M.S., Drasar, B.S. and Sack, R.B. (1993) The Aquatic Environment as a Reservoir of Vibrio cholerae: A Review. Journal of Diarrhoeal Diseases Research, 197-206.

[39] Cash, R.A., et al. (1974) Response of Man to Infection with Vibrio cholerae. I. Clinical, Serologic, and Bacteriologic Responses to a Known Inoculum. Journal of Infectious Diseases, 129, 45-52. https://doi.org/10.1093/infdis/129.1.45

[40] Longini Jr, I.M., et al. (2002) Epidemic and Endemic Cholera Trends over a 33-Year Period in Bangladesh. The Journal of Infectious Diseases, 186, 246-251. https://doi.org/10.1086/341206

[41] Alamanos, Y., et al. (2000) A Community Waterborne Outbreak of Gastro-Enteritis Attributed to Shigella sonnei. Epidemiology \& Infection, 125, 499-503. https://doi.org/10.1017/S0950268800004866

[42] Hara-Kudo, Y. and Takatori, K. (2011) Contamination Level and Ingestion Dose of Foodborne Pathogens Associated with Infections. Epidemiology \& Infection, 139, 1505-1510. https://doi.org/10.1017/S095026881000292X

[43] Zaman, K., et al. (1991) Surveillance of Shigellosis in Rural Bangladesh: A 10 Years Review. The Journal of the Pakistan Medical Association, 41, 75-78.

[44] Palaniappan, R. (1982) Studies on the Microflora on Prawns Penaeus indicus (Milne Edwards) (Crustacean decopoda, Penaedae) with Reference to Its Digestive System. PhD Thesis, Annamalai University.

[45] Parvez, A.K., et al. (2016) Bacteriological Quality of Drinking Water Samples across Bangladesh. Archives of Clinical Microbiology. 